\title{
The Implications of the Current Petroleum Reserves in Developed and Developing Nations
}

\author{
Isaac Festus O.*, Emereje Peter O. \\ Department of Mechanical Engineering, Delta State Polytechnic, Ogwashi-Uku, Delta State, Nigeria
}

Email address:

festusisaac@yahoo.com (Isaac F. O.)

To cite this article:

Isaac Festus O., Emereje Peter O.. The Implications of the Current Petroleum Reserves in Developed and Developing Nations. International Journal of Energy and Power Engineering. Vol. 4, No. 2, 2015, pp. 16-23. doi: 10.11648/j.ijepe.20150402.11

\begin{abstract}
We have seen that reserves are those quantities of petroleum claimed to be commercially recoverable by application of development projects to known accumulations under defined conditions and it must satisfy four criteria which must be: discovered through one or more exploratory wells, recoverable using existing technology, commercially viable and remaining in the ground. These conditions have actually be met by some oil producing countries but how long will they rely on it to maintain a stable economic growth and development. No matter the trillion of barrels of oil stored by most countries in the world especially Nigeria will still not guarantee continuous growth in economic stability since the rate of usage is far more than that of discovery. This paper was able to bring to the notice of everyone that petroleum reserves are very advisable to all developed and developing countries in order to guarantee a partial stable economic growth and development. Experience shows that initial estimates of the size of newly discovered oil fields are usually too low. As years pass, successive estimates of the ultimate recovery of fields tend to increase. The term reserve growth refers to the typical increases in estimated ultimate recovery that occur as oil fields are developed and produced. We are currently in an energy crisis. Fossil fuels are the lifeblood of our society and for many others around the world. Our supply has a finite end, which may make some countries to make friend with those they hate. The countries in the Middle East as we can see from Fig. 3 have the highest oil reserves in the world and as such every country wants to make friend with them in case of acute shortage. Despite this, fossil fuels will run out one day and it is important to find other means of getting the energy we need to continue our society as we know it.
\end{abstract}

Keywords: Petroleum Oil Reserves, Estimation Techniques, World Reserves Growth, Fossil Fuels, OPEC Countries, TOE

\section{Introduction}

This paper explains the significance and the implications of the current petroleum reserves, origination of fossil fuels, generation of electricity from its usage, and consumption of most developed and developing countries like Nigeria in Africa. Fossil fuels, coal, oil and natural gas, are nonrenewable source of energy formed from plants and animals that lived up to 300 million years ago. They are found in deposits beneath the earth. The fuels are burned to release the chemical energy that is stored within it. Energy is very essential to the modern society like Nigeria and other world countries as we know it. Over $85 \%$ of our energy demands are met by the combustion of fossil fuels. The pie charts in Figs. 1 and 2 show exactly how vital fossil fuels are to our society by showing how much of each energy resource is consumed [Bartok, W., and Sarofim, A. F. 1991].

Going back to the earlier days of earth, the plants and animals that lived then eventually died and decomposed. The majority of these life forms were phytoplankton and zooplankton. When these ancient ocean dwellers died, they accumulated on the bottom of seabed. This is how a good portion of our fossil fuel reserves began. The actual transformation process of these prehistoric creatures is not known, but scientists do know that the pressure, heat, and a great deal of time go into the making of fossil fuels [Bartok, W., and Sarofim, A. F. 1991].

Geologists are fairly certain that the beds of organic remains mixed with silt and mud to form layers. Over time, mineral sedimentation formed on top of the organisms, effectively entombing them in rock. As this occurred, pressure and temperature increased. These conditions, and possibly other unknown factors, caused organic material to break down into the simpler form of hydrocarbons: chains of carbon and hydrogen ranging from simple configuration to complex compounds. Another effect of extreme pressure is that the oil and gas which are various mixtures of 
hydrocarbons migrate upwards to the surface. Oil and gas are found in the ground, not freely drifting up through the earth. This is because the hydrocarbons come across rock formations that they are unable to penetrate. Complex rock structures that effectively trap gas and oil are formed by tectonic plate activity, the same forces that shift continents. Oil fields have been found everywhere on the planet except for the continent of Antarctica.

These fields always contain some gas, but this natural gas, methane, does not take nearly as long to form. Natural gas is also found in independent deposits within the ground as well as from other sources too. Methane is a common gas found in swamps and is also the byproduct of animals' digestive system. Incidentally, Methane is also a greenhouse gas [Seidel, S. 1983].

Coal is formed in a similar way to the fossil fuels, though it goes through a different process, coalification. Coal is made of decomposed plant matter in conditions of high temperature and pressure, though it takes a relatively shorter amount of time to form. Coal is not a uniform substance either; its composition varies from deposit to deposit. Factors that cause this deviation are the types of original plant matter, and the extent the plant matter decomposed. There are over 1200 distinguishable types of coal. Coal begins as peat, a mass of dead and decomposing plant matter. Peat itself has been used as fuel in the past, as an alternative to wood. Next, the peat becomes lignite, a brownish rock that contains recognizable plant matter and has a relatively low heating value. Lignite is the halfway point from peat to coal. The next phase is sub bituminous. A shade of dull black, showing very little plant matter, this type of coal has a less heating value. Bituminous coal is jet black, very dense, and brittle. This type of coal has high heating value [Bartok, W., and Sarofim, A. F. 1991].

With the current full dependency on the non-renewable energy source with over $80 \%$ usage then one can conclude that the present reserve by most countries will not still guarantee a stable economic growth since the rate of consumption is in geometric progression while that of oil discovery is in arithmetic progression.

More than $50 \%$ of the world electricity generation is derived from steam coal as shown in Fig. 1 and the most consumed energy comes from the natural gas as illustrated from Fig. 2.

Distillate Fuel $0.3 \%$, Residual Fuel $1.8 \%$, Natural Gas $10.7 \%$, Steam Coal 52.3\%, Nuclear Power 21.7\%, Renewable Energy $12.1 \%$, Electricity Imports $1.2 \%$ [Bartok, W., and Sarofim, A. F. 1991].

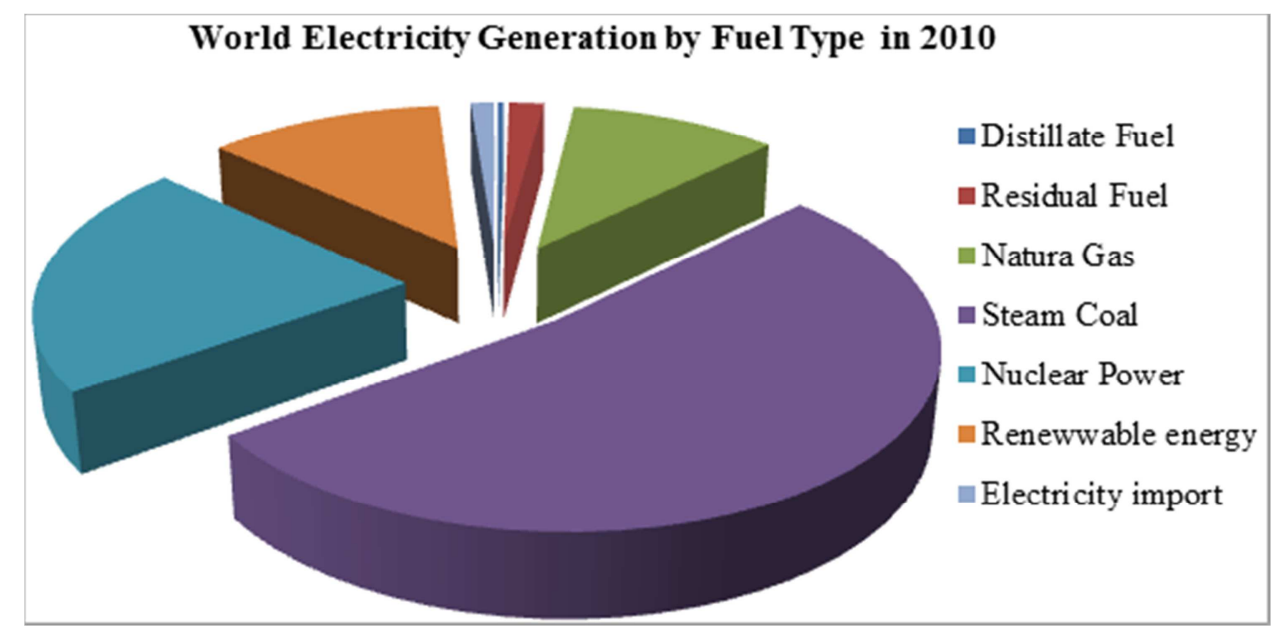

Fig. 1. Pie chart showing the world electricity generation by different fuel

Table 1. Percentage of different types of fuel generated

\begin{tabular}{ll}
\hline Distillate Fuel & $7.60 \%$ \\
Kerosene & $0.01 \%$ \\
Jet Fuel & $3.40 \%$ \\
Liquefied Petroleum Gas & $2.70 \%$ \\
Motor Gasoline & $16.40 \%$ \\
Petrochemical Feedstock & $1.30 \%$ \\
Residual Fuel & $2.40 \%$ \\
Other Petroleum & $4.50 \%$ \\
Natural Gas & $24.40 \%$ \\
Coal & $21.90 \%$ \\
Nuclear Power & $7.90 \%$ \\
Renewable Energy & $6.90 \%$ \\
Methanol & $0.10 \%$ \\
Liquid Hydrogen & $0.01 \%$ \\
Electricity Import & $0.40 \%$ \\
\hline
\end{tabular}




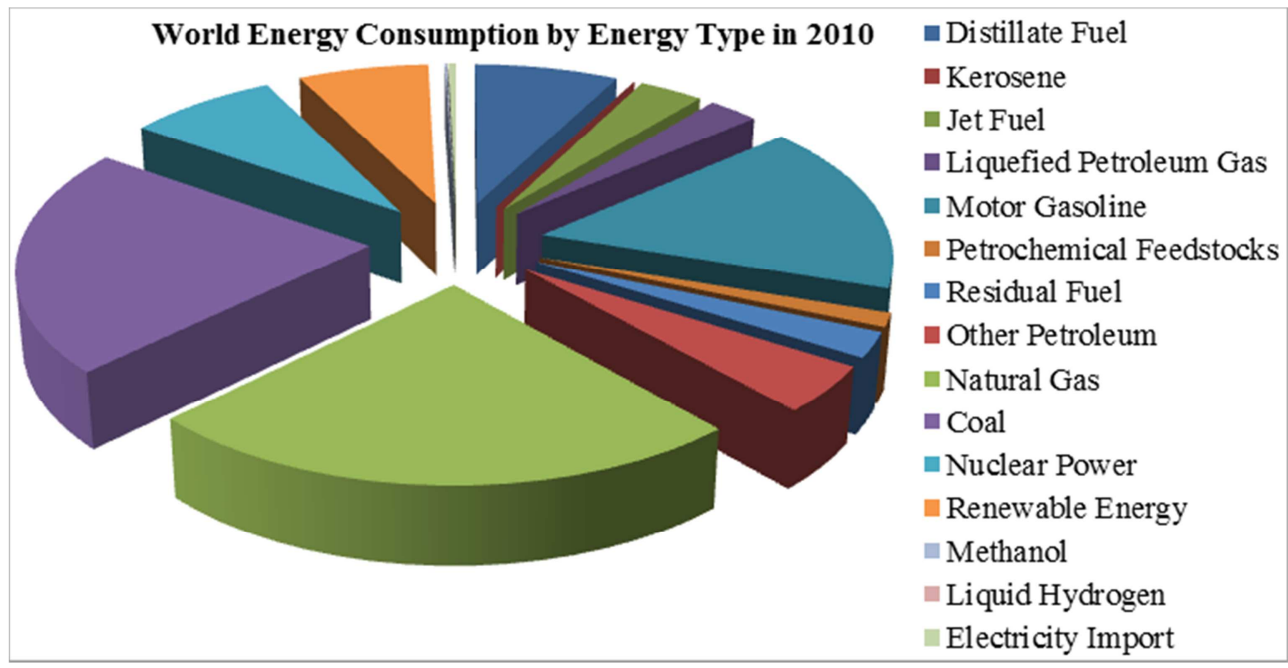

Fig. 2. Pie chart showing the world energy consumption from different fuel

\section{Problems with Fossil Fuel Usage in Nigeria}

Records have shown that Nigeria is the second largest oil producer in Africa after Libya and possibly one of the sixth largest exporters of oil in the world. The country is also a key member of OPEC. With this oil background, it is indeed ironic that power shortages occur with such frequency in the country. Some of the explanations that have frequently been volunteered for this endemic energy shortage in Nigeria are [Ismaila, A., Idris, B. G., and Tijani, B. N. 2009]:

i). Gross resource mismanagement;

ii). Persistent ethnic violence and eruption/vandalism of oil supply lines in the predominantly oil-producing regions of Nigeria;

iii). Negligence by subsequent Nigerian governments to invest in the energy sector and adapt energy development to local need;

iv). Poor distribution systems and even poorer maintenance of the few existing distribution systems. (It is estimated that —of the 79 power plants in the country, only 19 are operationall);

v). Sabotage and thefts of transmission lines which cause wide-spread power outages;

vi). Gross incompetence of politically-appointed power sector managers and poorly trained workers;

vii). A vulnerable grid layout that makes it easy for people to connect to their homes and even business without meters; and finally

viii). The well-documented endemic corruption in many other sectors of the Nigerian beaurocracy.

The best description of the current situation was reiterated by Nenadi Usman [Ismaila, A., Idris, B. G., and Tijani, B. N. 2009], Nigeria's former finance minister. He underscored the problem recently when he said; - South Africa generates 40,000 MW of electricity for her 45 million people. Meanwhile Nigeria, which has 140 million people, has barely 4,000 MW of capacity, and her production costs are five times higher.

Most businesses in Nigeria, large and small, end up relying on the generator for electricity to power their businesses. MTN-the South African mobile phone company and the largest mobile phone supplier in Nigeria-is estimated to -have installed 6,000 generators to supply its base stations for up to 19 hours a day. The company spends $\$ 5.5$ million a month on diesel fuel to run the generators.

The consequence of the energy shortage on Nigeria has been a stifling of economy opportunities and growth at the grassroots level. Perennial power outages stifle manufacturing and infrastructure development in the cities. Absence of electric power development in most of Nigeria's rural communities forces millions of families to rely on firewood for cooking, which in turn, impacts the environment. A documented trend estimates that over 300,000 hectares of deforestation occur per year in Nigeria due to a combination of rapid growth in the timber industry and domestic firewood dependency. Africa as whole is estimated to have lost 64 million hectares of forest between 1990 and 2005, more than any other continent, and firewood-gathering was the major cause of this depletion [Ismaila, A., Idris, B. G., and Tijani, B. N. 2009]. In addition, as stated earlier, millions of generators in both the cities and rural areas add to the stress on the environment. What is urgently needed to stem the assault on the environment, reverse the growing poverty trend and improve sanitation and the quality of life for the people is an investment in sustainable energy alternatives.

Two viable and sustainable energy technology enterprises that will have immediate positive effects on the lives of Nigerian citizens are (a) decentralized solar electric energy generation and (b) biogas generation through the development of biomass technology. These two sources of sustainable energy will not only improve the lives of urban and rural communities but will also be crucial in providing the energy needed to pump and purify water. This infrastructure is currently lacking or inadequate in most urban and rural communities of Nigeria, with catastrophic consequences so far. The development of wind energy source 
systems may become an option whose feasibility depends on the advancement of the relevant technology. Wind maps [Ismaila, A., Idris, B. G., and Tijani, B. N. 2009] that includes wind velocity distribution in Nigeria shows that rare winds may not sustain wind turbine at moderate pole heights. However, at other heights and using different technology, wind systems become very feasible.

\section{World Petroleum Reserves}

Reserves are those quantities of petroleum claimed to be commercially recoverable by application of development projects to known accumulations under defined conditions ["Petroleum Reserves Definitions" 1997]. Reserves must satisfy four criteria: They must be:

- discovered through one or more exploratory wells

- recoverable using existing technology

- commercially viable

- remaining in the ground

All reserve estimates involve uncertainty, depending on the amount of reliable geologic and engineering data available and the interpretation of those data. The relative degree of uncertainty can be expressed by dividing reserves into two principal classifications - "proven" (or "proved") and "unproven" (or "unproved"). Unproven reserves can further be divided into two subcategories - "probable" and "possible"- to indicate the relative degree of uncertainty about their existence. The most commonly accepted definitions of these are based on those approved by the Society of Petroleum Engineers (SPE) and the World Petroleum Council (WPC) in 1997 ["Petroleum Reserves Definitions" 1997].

\subsection{Proven Reserves}

Proven reserves are those reserves claimed to have a reasonable certainty (normally at least $90 \%$ confidence) of being recoverable under existing economic and political conditions, with existing technology. Industry specialists refer to this as (i.e., having a 90\% certainty of being produced). Proven reserves are also known in the industry as 1P [“Oil Reserves” 2008].

Proven reserves are further subdivided into "proven developed" (PD) and "proven undeveloped" (PUD). PD reserves are reserves that can be produced with existing wells and perforations, or from additional reservoirs where minimal additional investment (operating expense) is required. PUD reserves require additional capital investment (e.g., drilling new wells) to bring the oil to the surface.

Proved reserves are the only type the U.S. Securities and Exchange Commission allows oil companies to report to investors. Companies listed on U.S. stock exchanges must substantiate their claims, but many governments and national oil companies do not disclose verifying data to support their claims.

Unproven reserves are based on geological and/or engineering data similar to that used in estimates of proven reserves, but technical, contractual, or regulatory uncertainties preclude such reserves being classified as proven. Unproven reserves may be used internally by oil companies and government agencies for future planning purposes but are not routinely compiled. They are subclassified as probable and possible.

Probable reserves are attributed to known accumulations and claim a $50 \%$ confidence level of recovery. Industry specialists refer to them as (i.e., having a $50 \%$ certainty of being produced). These reserves are also referred to in the industry as $2 \mathrm{P}$ (proven plus probable) [Penwell Corporation 2007].

Possible reserves are attributed to known accumulations that have a less likely chance of being recovered than probable reserves. This term is often used for reserves which are claimed to have at least a $10 \%$ certainty of being produced. Reasons for classifying reserves as possible include varying interpretations of geology, reserves not producible at commercial rates, uncertainty due to reserve infill (seepage from adjacent areas) and projected reserves based on future recovery methods. They are referred to in the industry as $3 \mathrm{P}$ (proven plus probable plus possible).

\subsection{Strategic Petroleum Reserves}

Many countries maintain government-controlled oil reserves for both economic and national security reasons. According to the United States Energy Information Administration, approximately 4.1 billion barrels $\left(650,000,000 \mathrm{~m}^{3}\right)$ of oil are held in strategic reserves, of which 1.4 billion is government-controlled. These reserves are generally not counted when computing a nation's oil reserves.

A more sophisticated system of evaluating petroleum accumulations was adopted in 2007 by the Society of Petroleum Engineers (SPE), World Petroleum Council (WPC), American Association of Petroleum Geologists (AAPG), and Society of Petroleum Evaluation Engineers (SPEE). It incorporates the 1997 definitions for reserves, but adds categories for contingent resources and prospective resources ["Petroleum Reserves Definitions" 1997].

Contingent resources are those quantities of petroleum estimated, as of a given date, to be potentially recoverable from known accumulations, but the applied project(s) are not yet considered mature enough for commercial development due to one or more contingencies. Contingent resources may include, for example, projects for which there are currently no viable markets, or where commercial recovery is dependent on technology under development, or where evaluation of the accumulation is insufficient to clearly assess commerciality [Boes, E., and Taylor, R. 2003].

Prospective resources are those quantities of petroleum estimated, as of a given date, to be potentially recoverable from undiscovered accumulations by application of future development projects. Prospective resources have both an associated chance of discovery and a chance of development.

The United States Geological Survey uses the terms technically and economically recoverable resources when making its petroleum resource assessments. Technically 
recoverable resources represent that proportion of assessed in-place petroleum that may be recoverable using current recovery technology, without regard to cost. Economically recoverable resources are technically recoverable petroleum for which the costs of discovery, development, production, and transport, including a return to capital, can be recovered at a given market price.

Unconventional resources exist in petroleum accumulations that are pervasive throughout a large area. Examples include extra heavy oil, natural bitumen, and oil shale deposits. Unlike conventional resources, in which the petroleum is recovered through wellbores and typically requires minimal processing prior to sale, unconventional resources require specialized extraction technology to produce. For example, steam and/or solvents are used to mobilize bitumen for in-situ recovery. Moreover, the extracted petroleum may require significant processing prior to sale (e.g., bitumen upgraders). The total amount of unconventional oil resources in the world considerably exceeds the amount of conventional oil reserves, but is much more difficult and expensive to develop [World Proved Reserves of Oil and Natural Gas 2007].

\subsection{Estimation Techniques}

The amount of oil in a subsurface reservoir is called oil in place (OIP). Only a fraction of this oil can be recovered from a reservoir. This fraction is called the recovery factor. The portion that can be recovered is considered to be a reserve. The portion that is not recoverable is not included unless and until methods are implemented to produce it.

There are a number of different methods of calculating oil reserves. These methods can be grouped into three general categories: volumetric, material balance, and production performance. Each method has its advantages and drawbacks.

\subsection{Volumetric Method}

Volumetric methods attempt to determine the amount of oil in place by using the size of the reservoir as well as the physical properties of its rocks and fluids. Then a recovery factor is assumed, using assumptions from fields with similar characteristics. OIP is multiplied by the recovery factor to arrive at a reserve number. Current recovery factors for oil fields around the world typically range between 10 and 60 percent; some are over 80 percent. The wide variance is due largely to the diversity of fluid and reservoir characteristics for different deposits. The method is most useful early in the life of the reservoir, before significant production has occurred.

\subsection{Materials Balance Method}

The materials balance method for an oil field uses an equation that relates the volume of oil, water and gas that has been produced from a reservoir and the change in reservoir pressure to calculate the remaining oil. It assumes that, as fluids from the reservoir are produced, there will be a change in the reservoir pressure that depends on the remaining volume of oil and gas. The method requires extensive pressure-volume-temperature analysis and an accurate pressure history of the field. It requires some production to occur (typically $5 \%$ to $10 \%$ of ultimate recovery), unless reliable pressure history can be used from a field with similar rock and fluid characteristics.

\subsection{Production Decline Curve Method}

The decline curve method uses production data to fit a decline curve and estimate future oil production. The three most common forms of decline curves are exponential, hyperbolic, and harmonic. It is assumed that the production will decline on a reasonably smooth curve, and so allowances must be made for wells shut in and production restrictions. The curve can be expressed mathematically or plotted on a graph to estimate future production. It has the advantage of (implicitly) including all reservoir characteristics. It requires a sufficient history to establish a statistically significant trend, ideally when production is not curtailed by regulatory or other artificial conditions.

Again, the pie charts in Figs. 3 and 4 show the world oil reserves by region and the total world oil reserves [Rao, S., and Parulekar, B. B. 2004].

Asia \& Oceans 3\%, Africa 9\%, North America 16\%, Central \& South America 8\%, Europe 1\%, Eurasia 7\%, and Middle East 56\%.

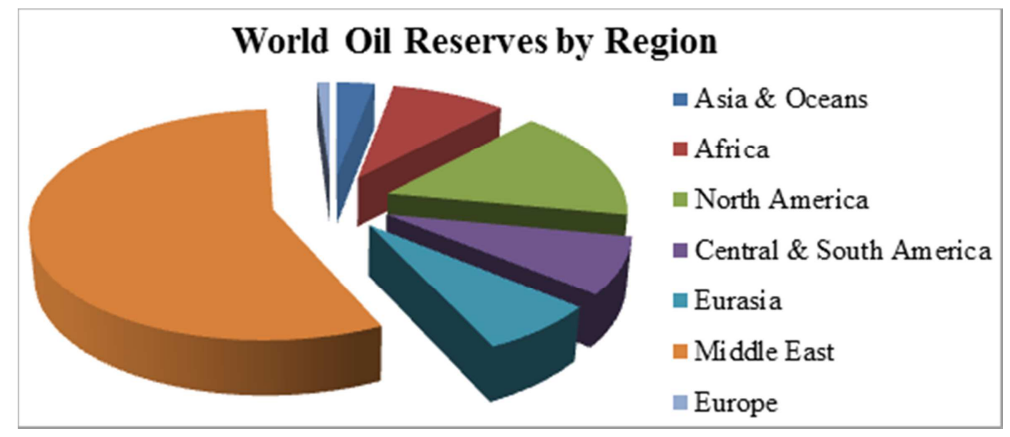

Fig. 3. Pie chart showing the world oil reserves

Oil Seed Bitumen 30\%, Conventional Oil 30\%, Heavy Oil 15\%, and Extra Heavy Oil 25\%. 


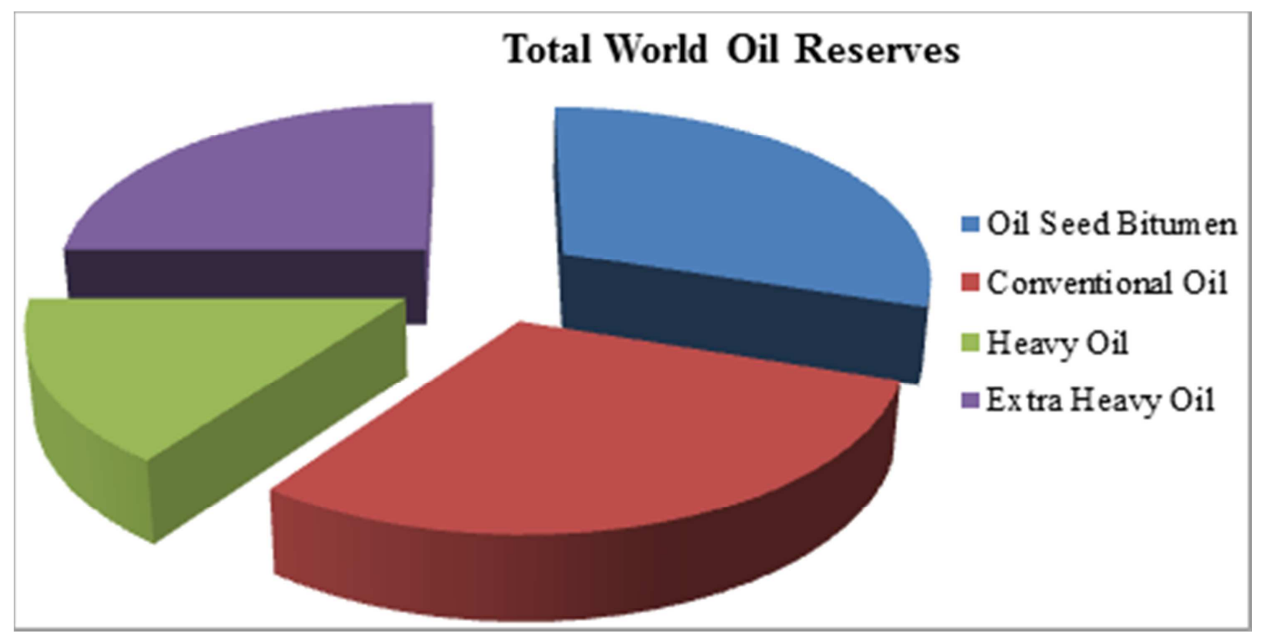

Fig. 4. Pie chart showing total world oil reserves

It's seen from Fig. 3 that most of the world's oil reserves are in the Middle East and in Fig. 4 the unconventional oil resources are greater than the conventional ones.

Nigeria has abundant reserves of energy resources. The dominant commercial energy resources are petroleum which is about 20 billion barrels, natural gas is between 2.7 and 8.1 billion $\mathrm{m}^{3}$ (100 and 300 Trillion Cubic Foot) bitumen and tar sand is about 159 million tons, Coal is about 639 million tons and hydro potentials is about $10,000 \mathrm{MM}$. The total installed electricity generating capacity is approximately $6,000 \mathrm{MW}$ made up of hydro, thermal (steam and gas) turbine plants, and about 15,000GWh-of electricity is generated in 1995. Fuel wood is estimated to be between 22.5MTOE and 64.7MTOE. Uranium deposits and various renewable energy sources are other primary sources. Solar energy is abundant with an average radiation level of $5.5 \mathrm{kWhm}^{-2}$ day $^{-1}$ and average wind speed is above $3 \mathrm{~ms}^{-1}$ in most part of the country $(1-7)$. The total energy consumption in 2005 is about 50MTOE with fuel wood accounting for about $47 \%$. Even though, crude oil accounts for $80 \%$ of Nigeria's export, the commercial energy consumption of petroleum products accounts for $44.3 \%$, natural gas $31 \%$, electricity $24.5 \%$ and coal $0.2 \%(1-4)$. The predominant role of crude oil does not reflect it level of endowment in the country. Table 2 shows the country's energy reserves. The endowment covers most of the known energy resources renewable and non-renewable [Ismaila, A., Idris, B. G., and Tijani, B. N. 2009].

Table 2. Nigeria's Energy Reserves.

\begin{tabular}{lllll}
\hline Resources & Reserves & Reserves (Billion toe) & \% Total Conventional Energy & Ref \\
\hline Crude Oil & $21 \mathrm{bbl}$ & 2.856 & 20.4 & $\mathrm{NNPC}$ \\
Natural Gas & 3615 billion $\mathrm{m}^{3}$ & 3.098 & 22.1 & 2 \\
Coal \& Lignite & 2.7 billion tons & 1.882 & 13.4 & 4 \\
Tar Sands & 31 billion bbl oil Equiv. (Preliminary Estimates) & 4.216 & 30.1 & 6 \\
Hydropower & $10,000 \mathrm{MW}$ & $1.954(100 \mathrm{yrs})$ & 14.0 & 2,3 \\
& Total Conventional Energy & 14.006 & 100.00 & \\
Fuel wood & 43.3 million tons $/ \mathrm{yr}$ & $1.645(100 \mathrm{yrs})$ & Tentative Estimate \\
Animal Waste \& Crop & 144 million tons $/ \mathrm{yr}$ & $3.024(100 \mathrm{yrs}$ and toe & Tentative Estimate \\
Residue & for dung cakes) & & \\
Small Scale Hydropower & $734.2 \mathrm{MW}$ & $0.143(100 \mathrm{yrs})$ & & \\
Solar Radiation & $3.5-7.0 \mathrm{KWh} / \mathrm{m}^{2}$-day (mean $=5.25 \mathrm{KWh} / \mathrm{m}^{2}-$ day) & $1.517 * *(100 \mathrm{yrs})$ & & 10 \\
Wind & $2-4 \mathrm{~m} / \mathrm{s}$ & $\mathrm{NA}$ & & 13 \\
& Total, excldg. Wind & 20.192 & \\
\hline
\end{tabular}

TOE $=$ tons oil equivalent, 1 Barrel of oil $=0.136$ tons of oil $100 \mathrm{~m}^{3}$ Natural Gas $=0.857$ TOE 1 Ton of Coal $=0697 \mathrm{TOE}$

Source: [Ismaila, A., Idris, B. G., and Tijani, B. N. 2009]

\section{World Reserves Growth}

Experience shows that initial estimates of the size of newly discovered oil fields are usually too low. As years pass, successive estimates of the ultimate recovery of fields tend to increase. The term reserve growth refers to the typical increases in estimated ultimate recovery that occur as oil fields are developed and produced. Table 3 shows the summary of reserve data as of 2010 [U.S. Energy Information Administration (EIA)]. 
Table 3. Summary of reserve data as of 2010.

\begin{tabular}{|c|c|c|c|c|c|}
\hline \multirow{2}{*}{ Country } & \multicolumn{2}{|c|}{ Reserves } & \multicolumn{2}{|c|}{ Production } & \multirow{2}{*}{$\begin{array}{l}\text { Reserve life }^{1} \\
\text { Years }\end{array}$} \\
\hline & $10^{9} \mathrm{bbl}$ & $10^{9} \mathrm{~m}^{3}$ & $10^{6} \mathrm{bbl} / \mathrm{d}$ & $10^{3} \mathrm{~m}^{3} / \mathrm{d}$ & \\
\hline Venezuela & 297 & 47.2 & 2.7 & 430 & 301 \\
\hline Saudi Arabia & 267 & 42.4 & 9.7 & 1,540 & 75 \\
\hline Canada & 179 & 28.5 & 2.1 & 330 & 188 \\
\hline Iraq & 143 & 22.7 & 3.5 & 560 & 112 \\
\hline Iran & 138 & 21.9 & 4.0 & 640 & 95 \\
\hline Kuwait & 104 & 16.5 & 2.6 & 410 & 110 \\
\hline Russia & 60 & 9.5 & 9.9 & 1,570 & 17 \\
\hline Kazakhstan & 47 & 7.5 & 1.4 & 220 & 93 \\
\hline Libya & 41 & 6.5 & 1.7 & 270 & 66 \\
\hline Nigeria & 36 & 5.7 & 2.4 & 380 & 41 \\
\hline United States & 21 & 3.3 & 7.5 & 1,190 & 8 \\
\hline China & 16 & 2.5 & 3.9 & 620 & 11 \\
\hline Qatar & 15 & 2.4 & 0.9 & 140 & 46 \\
\hline Brazil & 12 & 1.9 & 2.3 & 370 & 14 \\
\hline Mexico & 12 & 1.9 & 3.5 & 560 & 9 \\
\hline Total of top seventeen reserves & 1,243 & 197.6 & 63.5 & 10,100 & 54 \\
\hline
\end{tabular}

\section{OPEC Countries}

There are doubts about the reliability of official OPEC reserves estimates, which are not provided with any form of audit or verification that meet external reporting standards.

Since a system of country production quotas was introduced in the 1980s, partly based on reserves levels, there have been dramatic increases in reported reserves among OPEC producers. In 1983, Kuwait increased its proven reserves from $67 \mathrm{Gbbl}\left(10.7 \times 10^{9} \mathrm{~m}^{3}\right)$ to $92 \mathrm{Gbbl}\left(14.6 \times 10^{9}\right.$ $\mathrm{m}^{3}$ ). In 1985-86, the UAE almost tripled its reserves from 33
Gbbl $\left(5.2 \times 10^{9} \mathrm{~m}^{3}\right)$ to $97 \mathrm{Gbbl}\left(15.4 \times 10^{9} \mathrm{~m}^{3}\right)$. Saudi Arabia raised its reported reserve number in 1988 by $50 \%$. In $2001-$ 02 , Iran raised its proven reserves by some $30 \%$ to $130 \mathrm{Gbbl}$ $\left(21 \times 10^{9} \mathrm{~m}^{3}\right)$, which advanced it to second place in reserves and ahead of Iraq. Iran denied accusations of a political motive behind the readjustment, attributing the increase instead to a combination of new discoveries and improved recovery. No details were offered of how any of the upgrades were arrived at ["Petroleum Reserves Definitions" 1997].

Table 3 illustrates these rises.

Table 4. Declared reserves of major OPEC Producers (billion of barrels).

\begin{tabular}{|c|c|c|c|c|c|c|c|c|}
\hline \multicolumn{9}{|c|}{ BP Statistical Review - June 2009} \\
\hline Year & Iran & Iraq & Kuwait & Saudi Arabia & UAE & Venezuela & Libya & Nigeria \\
\hline 1980 & 58.3 & 30.0 & 67.9 & 168.0 & 30.4 & 19.5 & 20.3 & 16.7 \\
\hline 1981 & 57.0 & 32.0 & 67.7 & 167.9 & 32.2 & 19.9 & 22.6 & 16.5 \\
\hline 1982 & 56.1 & 59.0 & 67.2 & 165.5 & 32.4 & 24.9 & 22.2 & 16.8 \\
\hline 1983 & 55.3 & 65.0 & 67.0 & 168.8 & 32.3 & 25.9 & 21.8 & 16.6 \\
\hline 1984 & 58.9 & 65.0 & 92.7 & 171.7 & 32.5 & 28.0 & 21.4 & 16.7 \\
\hline 1985 & 59.0 & 65.0 & 92.5 & 171.5 & 33.0 & 54.5 & 21.3 & 16.6 \\
\hline 1987 & 92.9 & 100.0 & 94.5 & 169.6 & 98.1 & 58.1 & 22.8 & 16.0 \\
\hline 1988 & 92.9 & 100.0 & 94.5 & 255.0 & 98.1 & 58.5 & 22.8 & 16.0 \\
\hline 1989 & 92.9 & 100.0 & 97.1 & 260.1 & 98.1 & 59.0 & 22.8 & 16.0 \\
\hline 1990 & 92.9 & 100.0 & 97.0 & 260.3 & 98.1 & 60.1 & 22.8 & 17.1 \\
\hline 1991 & 92.9 & 100.0 & 96.5 & 260.9 & 98.1 & 62.6 & 22.8 & 20.0 \\
\hline 1992 & 92.9 & 100.0 & 96.5 & 261.2 & 98.1 & 63.3 & 22.8 & 21.0 \\
\hline 1993 & 92.9 & 100.0 & 96.5 & 261.4 & 98.1 & 64.4 & 22.8 & 21.0 \\
\hline 1995 & 93.7 & 100.0 & 96.5 & 261.5 & 98.1 & 66.3 & 29.5 & 20.8 \\
\hline 1996 & 92.6 & 112.0 & 96.5 & 261.4 & 97.8 & 72.7 & 29.5 & 20.8 \\
\hline 1997 & 92.6 & 112.5 & 96.5 & 261.5 & 97.8 & 74.9 & 29.5 & 20.8 \\
\hline 1998 & 93.7 & 112.5 & 96.5 & 261.5 & 97.8 & 76.1 & 29.5 & 22.5 \\
\hline 1999 & 93.1 & 112.5 & 96.5 & 262.8 & 97.8 & 76.8 & 29.5 & 29.0 \\
\hline 2000 & 99.5 & 112.5 & 96.5 & 262.8 & 97.8 & 76.8 & 36.0 & 29.0 \\
\hline 2001 & 99.1 & 115.0 & 96.5 & 262.7 & 97.8 & 77.7 & 36.0 & 31.5 \\
\hline 2002 & 130.7 & 115.0 & 96.5 & 262.8 & 97.8 & 77.3 & 36.0 & 34.3 \\
\hline 2003 & 133.3 & 115.0 & 99.0 & 262.7 & 97.8 & 77.2 & 39.1 & 35.3 \\
\hline 2004 & 132.7 & 115.0 & 101.5 & 264.3 & 97.8 & 79.7 & 39.1 & 35.9 \\
\hline 2005 & 137.5 & 115.0 & 101.5 & 264.2 & 97.8 & 80.0 & 41.5 & 36.2 \\
\hline 2006 & 138.4 & 115.0 & 101.5 & 264.3 & 97.8 & 87.3 & 41.5 & 36.2 \\
\hline
\end{tabular}




\begin{tabular}{lllllllll}
\hline \multicolumn{2}{l}{ BP Statistical Review } & June 2009 & & & & & \\
\hline Year & Iran & Iraq & Kuwait & Saudi Arabia & UAE & Venezuela & Libya & Nigeria \\
\hline 2007 & 138.2 & 115.0 & 101.5 & 264.2 & 97.8 & 99.4 & 43.7 & 36.2 \\
2008 & 137.6 & 115.0 & 101.5 & 264.1 & 97.8 & 99.4 & 43.7 & 36.2 \\
\hline
\end{tabular}

The sudden revisions in OPEC reserves, totaling nearly 300 billion of barrels, have been much debated. Some of it is defended partly by the shift in ownership of reserves away from international oil companies, some of whom were obliged to report reserves under conservative US Securities and Exchange Commission rules. The most prominent explanation of the revisions is prompted by a change in OPEC rules which set production quotas (partly) on reserves. In any event, the revisions in official data had little to do with the actual discovery of new reserves.

Total reserves in many OPEC countries hardly changed in the 1990s. Official reserves in Kuwait, for example, were unchanged at $96.5 \mathrm{Gbbl}\left(15.34 \times 10^{9} \mathrm{~m}^{3}\right)$ (including its share of the Neutral Zone) from 1991 to 2002, even though the country produced more than $8 \mathrm{Gbbl}\left(1.3 \times 10^{9} \mathrm{~m}^{3}\right)$ and did not make any important new discoveries during that period. The case of Saudi Arabia is also striking, with proven reserves estimated at between 260 and 264 billion barrels $\left(4.20 \times 10^{10}\right.$ $\mathrm{m}^{3}$ ) in the past 18 years, a variation of less than $2 \%$, while extracting approximately 60 billion barrels $\left(9.5 \times 10^{9} \mathrm{~m}^{3}\right)$ during this period.

Sadad al-Huseini, former head of exploration and production at Saudi Aramco, estimates $300 \mathrm{Gbbl}\left(48 \times 10^{9} \mathrm{~m}^{3}\right)$ of the world's 1,200 Gbbl $\left(190 \times 10^{9} \mathrm{~m}^{3}\right)$ of proven reserves should be recategorized as speculative resources, though he did not specify which countries had inflated their reserves. Dr. Ali Samsam Bakhtiari, a former senior expert of the National Iranian Oil Company, has estimated that Iran, Iraq, Kuwait, Saudi Arabia and the United Arab Emirates have overstated reserves by a combined 320-390bn barrels and has said, "As for Iran, the usually accepted official 132 billion barrels $\left(2.10 \times 10^{10} \mathrm{~m}^{3}\right)$ is almost one hundred billion over any realistic assay. Petroleum Intelligence Weekly reported that official confidential Kuwaiti documents estimate reserves of Kuwait were only 48 billion barrels $\left(7.6 \times 10^{9} \mathrm{~m}^{3}\right)$, of which half were proven and half were possible. The combined value of proven and possible is half of the official public estimate of proven reserve ["Petroleum Reserves Definitions" 1997].

\section{Conclusions}

We have seen that reserves are those quantities of petroleum claimed to be commercially recoverable by application of development projects to known accumulations under defined conditions and it must satisfy four criteria which must be: discovered through one or more exploratory wells, recoverable using existing technology, commercially viable and remaining in the ground. These conditions have actually be met by some oil producing countries but how long will they rely on it to maintain a stable economic growth and development. No matter the trillion of barrels of oil stored by most countries in the world especially Nigeria will still not guarantee continuous growth in economic stability since the rate of usage is far more than that of discovery.

We are currently in an energy crisis. Fossil fuels are the lifeblood of our society and for many others around the world. Our supply has a finite end, which may make some countries to make friend with those they hate. The countries in the Middle East as we can see from Fig. 3 have the highest oil reserves in the world and as such every country wants to make friend with them in case of acute shortage. Despite this, fossil fuels will run out one day and it is important to find other means of getting the energy we need to continue our society as we know it.

\section{References}

[1] Bartok, W., and Sarofim, A. F. (1991). Fossil Fuel Combustion, a Source Book. John Wiley and Sons, Inc., New York.

[2] Boes, E., and Taylor, R. (2003). Understanding U.S. Strategic Interests in Expanding Renewable Energy Systems Worldwide-Summary of the Third NREL Energy Analysis Forum, Washington, DC, USA.

[3] Ismaila, A., Idris, B. G., and Tijani, B. N. (2009). Renewable Energy Applications in Nigeria. An International Journal of Engineering Science Published by the International Research and Development Institute, Uyo. Vol. 1, No. 2, Pp 1-2.

[4] Nwaka, G.I. (2005). The urban informal sector in Nigeria: Towards economic development, environmental health, and social harmony. Global Urban Development Magazine.

[5] "Oil Reserves" (2008). BP Global.

[6] Penwell Corporation (2007). Oil and Gas Journal, Vol. 105.

[7] "Petroleum Reserves Definitions" (1997). Petroleum Resource Management system. Society of Petroleum Engineers.

[8] Rao, S., and Parulekar, B. B. (2004). Energy Technology Nonconventional, renewable and Conventional, Third Edition. Khama Publishers, Nai Sarak, Delhi-india.

[9] Seidel, S. (1983). Can We Delay a Greenhouse Warming? Strategic Studies Staff, Office of Policy Analysis, Washington, D. C.

[10] U.S. Energy Information Administration (EIA). U.S. Government. U.S. Department of Energy, Petroleum Data, Reports, Analysis, Surveys.

[11] World Proved Reserves of Oil and Natural Gas (2007). US Energy Information Administration. 